\title{
CONCEPTION OF THE TRACK SYSTEM FOR „DĘBIEŃSKO 1” MINING PLANT
}

\author{
Ryszard MIELIMĄKA, Justyna ORWAT, Ewa MACIEJOWSKA-FIGIEL \\ Silesian University of Technology
}

\begin{abstract}
:
This article presents two concepts of site development for the „Dębieńsko 1" mining plant including plans for the track system. The first plan was created in 2013 year and mainly assumed the renovation of railway infrastructure, without changing its shape and configuration. In 2014 year it was resigned from realization of the first conception and there was proposed the second plan. It included changes in the existing track system and project of the new system of excavated raw material haulage. This system is successfully using in the USA and provides the better work productivity of a shunting locomotive. In this article also were indicated the advantages and the disadvantages of solutions proposed in the two projects of site development plans. It was denoted the project that has ultimately been chosen with the justification of choice.
\end{abstract}

Key words: „Dębieńsko 1" mining plant, area development planning, site development project, output haulage, track system

\section{INTRODUCTION}

The launch of the „Dębieńsko 1" mining plant on the premises of the cinders of the former Dębieńsko hard coalmine is an exceptional event in whole Central Europe. Deposits located in this Upper Silesian Coal Basin are one of the last unexplored coke deposits in the area.

In 2008, the company „Karbonia S.A." obtained 50-year license for extraction of bituminous coal and coal bed methane in the mining area [7] that is located on the grounds of Rybnik and Knurów towns and also CzerwionkaLeszczyny and Ornontowice municipalities. The company is a part of the international firm New World Resources N.V., which is one of the leader producers of carbon and coke in Central Europe. The Dębieńsko coalmine, compliant with the latest mining regulations, will operate as an independently exploiting unit, using the most modern mining plant.

The strategic location of Dębieńsko town, mainly its close proximity of the Central Europe's biggest smelters and steelworks, which are a group of low risk clients, generates the possibility to get competitive price for coke as compared to other coal producers on the market. The carbon is to be delivered mainly by means of railway transport. There is the railway infrastructure available in the area where "Dębieńsko 1" mining plant is to be launched, however it requires an extensive reconstruction and development.

This article presents the projects for „Dębieńsko 1" mining plant site development including two concepts for tracks structure.

\section{„DĘBIEŃSKO 1” MINING PLANT SITE DEVELOPMENT PRO- JECTS}

In order to identify and interpret the proper location of the track system, it is necessary to get acquainted with the projects of the mining plant's site development.
There have been two site development plans for „Dębieńsko 1" mining plant. These plans have been prepared in compliance with:

- Zoning Plan for Czerwionka-Leszczyny municipality in force [2],

- current Study of Land Use Conditions and Directions of Czerwionka-Leszczyny [4].

Both area development projects have been prepared in accordance with the principal design brief, which included among others: mine shaft function, number of crew members, coalmine drainage and ways of mine water utilisation. Apart from that, the client imposed the location of the demethanization station and the method of output haulage from the coal mechanical processing plant.

It is necessary to add that on the area in question there are buildings that previously belonged to the former Dębieńsko HCM, among others: energy company "Megawat”, active coke plant and energy station buildings. Some of them have been registered as objects of cultural heritage [1]. These objects are: pithead building, workshop, water treatment facility, electricity distribution building and coalmine headquarters building. It is suggested that "Karbonia” S.A should use the mentioned buildings.

\section{The first plan of site development}

The first project has been based on the Zoning Plan for a part of the area, under the name "Dębieńsko 1" [1]. On this basis, it has been divided to the following areas:

- area of production facilities development,

- area of warehouse and depot development,

- area intended as a dumping ground for mining waste,

- area of power infrastructure,

- area of internal roads of the mining plant.

After having analysed the input materials, i.e. the above mentioned site development plan and cadastral maps, it 
was found that the first conception designated for coalmine development is suitable in terms of the area size, localization and transport connections.

The project no. 1 assumes usage of the active Mine Shaft Jan III. It also suggests that the objects situated in the area designated for construction of a new Mine Shaft I should be adequately dismantled, that is the landing, which includes bunched wires that supply power to the recipients on the grounds of the former coalmine but also beyond it. This is logistically problematic to a certain extent as it is necessary to ensure continuity of power supplies, however it is essential for sinking the Shaft I.

The first idea assumed that for proper operation of the newly created coalmine, it is necessary to build two additional shafts (not including the Shaft I), i.e. Shaft VII and Shaft VIII. Besides that, it has proposed to build a new lifting facility.

The project also postulates that it will be indispensable to perform grading of the terrain in order to enable drainage of meteoric water from the Shaft VIII. Water tanks have been designed in the northern and southern sides.

The anticipated demethanization station is to be situated at the peripheries of the enclosed territory. Methane pumping is supposed to take place directly from the deposits.

The dumping grounds together with the freight infrastructure have been designed in the southern side of the warehouse places. Additionally, this area is supposed to include garages and parking places for the vehicles that operate in the dumping grounds. This part of the terrain is also supposed to include coalmine sediment tanks for mine water and sediment tank for leachate waters from dumps.

General design in the first project included good solutions, nevertheless there have been some shortcomings that have been analysed and corrected by the second conception. The mentioned defects are: not enough reserve of the area designated for construction of the Shaft VII, great amount of excavations required in relation to terrain grading (its substantial elevation differences) and clearance of trees, designed coalmine buildings too scattered, electric line development collision, waste from the former coalmine Dębieńsko located in the ground presumably preventing development of considerable cubic objects and sediment tanks designed in the embankment area, which would cause a necessity to pump sewage $[3,5]$.

The second plan of site development

The conception no. 2 has created four site development proposals on the basis of the first idea.

Variant 0 has been only a supplement to the first project with specifications and excavation costs estimates.

Variant I presented optimum usage of the referred area and it emphasized the altitude landform, in order to reduce cost related to excavations.

Variant II additionally reduced development in the area of Shaft VIII and changed location of the dumping grounds and demethanization station to the northern part of the area.

The last variant III has been created to meet the investor's request to build car parks nearby Shaft VIII, intending to facilitate employees to commute to work from the residential development area located to the south from the shaft. This variant also predicted the dumping grounds in the northern part of the area.
After a thorough analysis of all the proposals, „Karbonia" S.A. has decided upon the variant I plan execution.

It predicts employees' car parks located in the neighbourhood of the cones, which are historic soil masses remaining after the former Dębieńsko coalmine operation.

It has been decided to situate cubic objects, such as fans stations of the Shaft I, on the subsoil ground near railway tracks, which will allow reducing excavation works substantially. In relation to the limited area near the Shaft VII, it has been decided to install lifting equipment on the shaft head frame. The electric line which collided in first project has been predicted to be wired and moved closer to railway tracks. The Shaft VIII is supposed to have a separate entry from the Przemysłowa Street side and a car park for the crew. A high-density development of cubic objects (e.g. bathhouse, mine rescue service buildings) allows reducing the area designated for levelling (in comparison to the first solution) by as much as $50 \%$. In the second project, the plans for development of the peripheral eastern part of the area have been waived because of the existing trees. The location of the sediment water tank has been predicted to be in the lowest point of the square in Shaft VIII, which has not excluded the need to pump mine waters from the distant parts of the plant, but it significantly facilitates the waters gravitational flow $[3,6]$.

All these factors have made the second proposition of site development more functional and cost-efficient in regards to excavation works, trees clearance, etc.

\section{CONCEPTS OF THE TRACK SYSTEM}

The projects of the „Dębieńsko 1" mining plant site development have been prepared for both coalmine infrastructure and railway tracks leading to it, that will be the basis for the efficient output haulage from the coalmine premises. The assumed design brief (described in section 2 ), besides shaft function or the number of staff members, also determines that the carbon extract haulage from the mechanical processing plant in the major part will be done by means of railway transport.

\section{Project of the track system in the first conception}

The first project of the site development assumes the mine railway station is to be entirely reconstructed with the track and electrical traction in the 1:1 ratio, without any changes. Within the railway station premises, there will also be a signal tower and fuel station for railway engines. The transport connection with the Shaft VIII has been designed as a narrow gauge track system operated by a diesel locomotive garaged in the terminal.

A direct disadvantage of the concept of the track system in the project no. 1 is the fact that the elevation spans in the area of the Shaft VIII are up to 10-16 meters, which would require additional excavation works, which generate high costs.

Moreover, the designed buildings complex is highly scattered. This in turn may cause cost increase related to the output transportation between particular site objects that are distant to one another and the necessity to level a large area of ground.

Particularly, the narrow gauge track system has to be taken into consideration, as its location depends on the elevation ordinate of the shaft's outset. In this area, the level of top of the track bed must not be higher that 252.5 meters above sea level. 
On the other hand, the ordinate of subsoil in this place is estimated as $254-255$ meters above sea level. This makes it necessary to execute excavation works and to level out the area to the altitude of the shaft's outset (Figure 1).

Moreover, the locomotive terminal is situated at a significant distance from the shaft - over $300 \mathrm{~m}$.

\section{Project of the track system in the second conception}

In the second project have been designed the tracks of the plant station in the cross-section layout (marked with red colour in the Figure 2), parallel to the existing group of railway siding tracks, located in the odd side of the railway line (marked with green colour in the Figure 2).

The second project assumes usage of the existing railway infrastructure after its renovation. It is planned to do renovation works of tracks no. 1, 3 and 5, which includes track beds repair with total replacement of the surface, compliant with the newly designed tracks.

Unfortunately, the current state of the track beds is not satisfactory - numerous deformations are present. The reason for that lies in the waterlogged track beds, as water is not drained properly. This in turn is the cause for limited load-bearing capacity of the tracks during their exploitation. In order to increase durability and lifetime of the old and newly designed tracks, it is planned to build up the protection layer with a filtering layer out of mineral aggregate, minimum $0.20 \mathrm{~m}$ thick and laid on geotextile. After such track bed has been applied, it is expected to attain minimum deformation modulus equal $90 \mathrm{MPa}$. Also, the project includes tracks' crosswise inclination with gradient reaching 3 to $5 \%$, which will help to drain water from the tracks quicker. Additionally, a track with the fuel distributor is to have a tanked basement constructed.



Fig. 1 Integration of loT devices with social media

Source: [5].

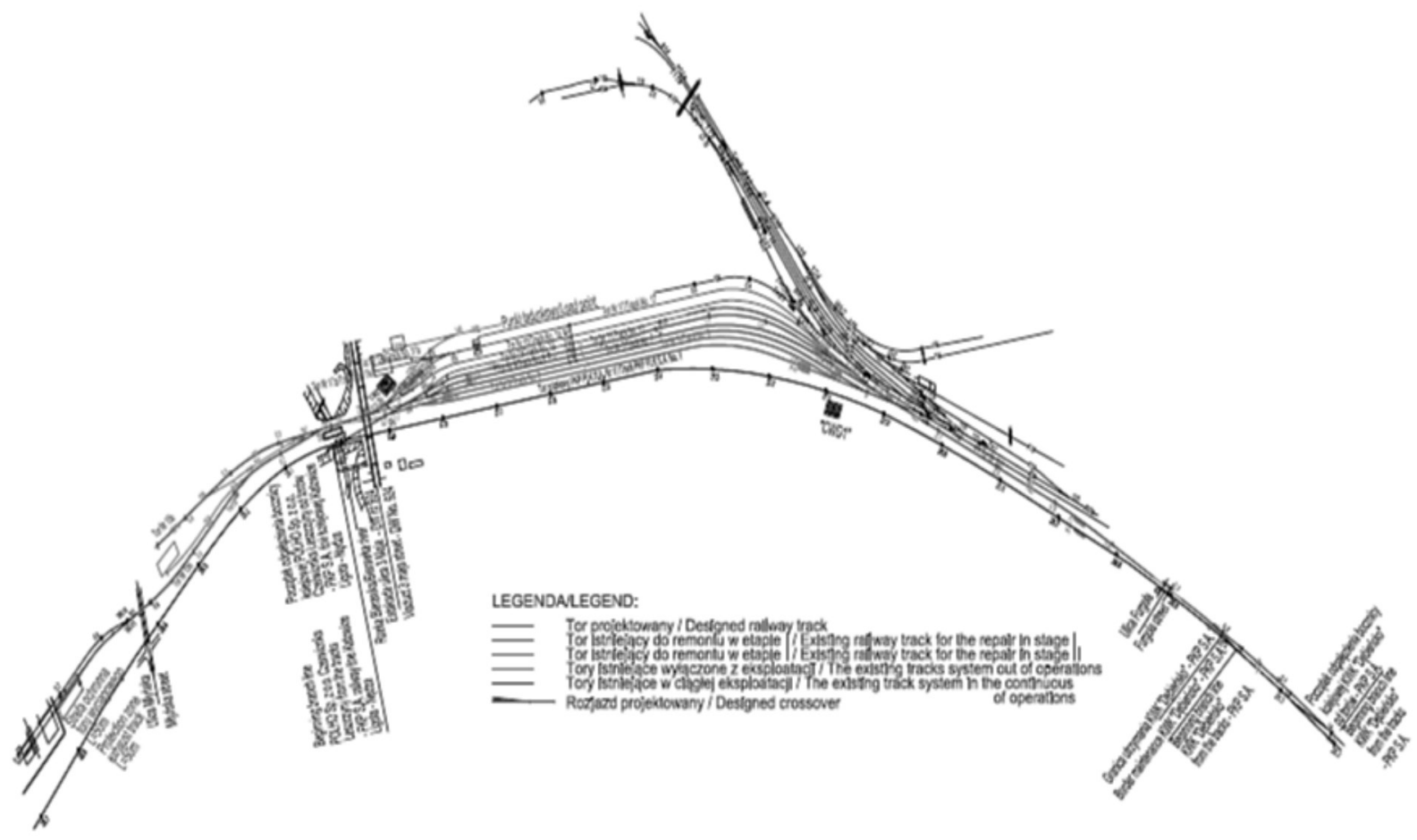

Fig. 2 Project of the track system of the plant railway station in the second idea Source: [6]. 
The new tracks are designed towards the north side from the existing ones and have consecutive numbers:

- track no. 7 - dispatch and collect track of minimal utilizable length $650 \mathrm{~m}$,

- track no. 9 - dispatch and collect track of minimal utilizable length $650 \mathrm{~m}$,

- track no. 11 - dispatch and collect track of minimal utilizable length $650 \mathrm{~m}$,

- track no. 13 - dispatch and collect track of minimal utilizable length $650 \mathrm{~m}$,

- track no. 15 - siding track of minimal utilizable length $650 \mathrm{~m}$,

- track no. 17 - freight track of minimal utilizable length $650 \mathrm{~m}$,

- track no. 15a - lift track of minimal utilizable length $620 \mathrm{~m}$ (south - west),

- track no. $15 b$ - side track of minimal utilizable length $250 \mathrm{~m}$ (south - west),

- track no. 17a - track leading to the plant locomotive terminal (north - west),

- track no. 17b - track leading to the plant locomotive terminal with a fuel distributor (north - west),

- track no. 100 - subsidiary track - connection of the coalmine station system with PKP PLK S.A. trail (south - east).

The designed layout is to have nominal track gauge equal to $1435 \mathrm{~mm}$. The surface underneath the tracks is to be made of blinding concrete on gravel ballast, $21 \mathrm{~cm}$ thick. For a railroad switch, curves and turnouts, wooden base is to be used. At the endings of the lift track there will be rail and concrete buffer stops with a bumper device placed in the plant's locomotive terminal hall. The projected tracks will have a minimum horizontal radius of curve equal to 190 $m$. For the tracks laid in stations, the spacing between the freight track and the closest dispatch track will be equal to $9.0 \mathrm{~m}$, while for other tracks, the spacing will be between 4.5 to $6.0 \mathrm{~m}$. Tracks in stations will have a profile bound to the height of the trail track no. 1 and will be linked to the turnouts no. 15 and no. 20. A new dispatch and collect track has been designed with inclination angle from $2.2 \%$ to $4.2 \%$, which has been adjusted to other existing dispatch and collect tracks. The track no. 15 and the freight track no. 17 will be inclined maximum to $2.5 \%$. The tracks at the weight segment are designed as horizontal ones. The track no. 100 is to be linked to the already replaced ending track spans as their surface remains in good condition for $20 \mathrm{~m}$ of its length (in front of and beneath the crossing along Furgota Street).

The concept of the track system assumes cross-wise and longitudinal drainage. It is planned to install a drain pipeline (underneath ground frost depth) with inspection manholes with filtering backfill. Moreover, a deep-seated drainage has been planned in the space between the tracks 15-17. The entire drained water is to be discharged to the nearby Bierawka River, after having been treated in the filtering wells. The main task of drainage processes is to increase track beds stability and ground resistance during exploitation. It will also have influence on the proper functioning of the buildings and equipment located nearby the track beds.

The project envisions operation of the whole siding track from only one traffic control, located in the building no. K.3 (Figure 3). In order to allow the siding track to function efficiently, it is necessary to install electrical heating for the railroad switches. It is recommended to assemble a television surveillance mast. It will enable video transmission to the traffic control point and the property security cabins. In order to improve loading and delivery of feedstock, in the second project has been suggested shipment technology based on the systems used in the United States. What is characteristic about these systems is that at its runtime, the loading equipment weights an output portion, which is afterwards dropped to a discharge hopper, located above a passing railway carriage. Individual railway carriages move at a speed of $0.5 \mathrm{~m} / \mathrm{s}$, hence the loading time for a $600 \mathrm{~m}$ set of cars will total to 18 minutes. The locomotive that belongs to the investor, i.e. „Karbonia” S.A., allows for full operation of five sets of train cars, each $600 \mathrm{~m}$ long, within twenty four hours.

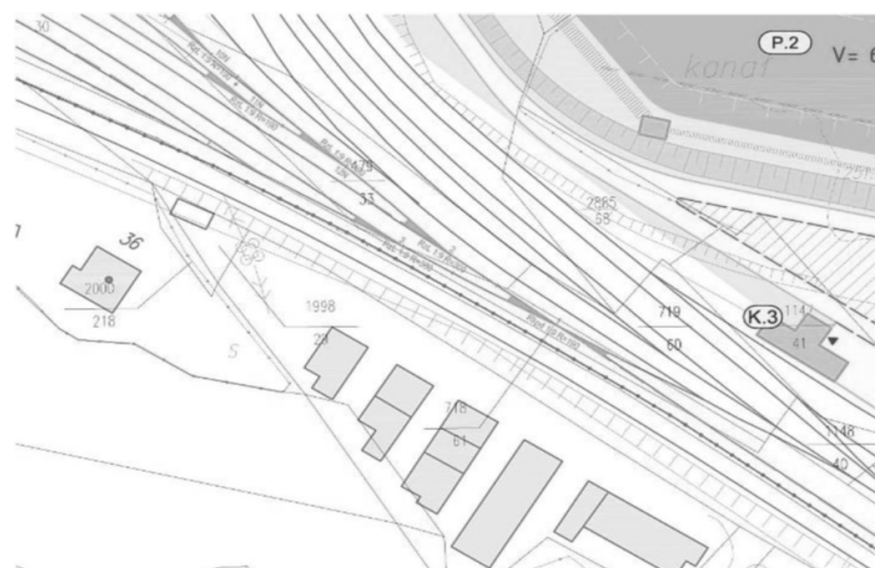

Fig. 3 Excerpt from „Dębieńsko 1" mining plant site development plan - traffic control building Source: [6].

This system determines technology of the siding track operation divided into the following stages:

1. Admission of a train carriages set at the dispatch and collect tracks (Figure 4).

2. Pulling out of the whole train cars set from the dispatch and collect track to the lift track (Figure 5).

3. Shunting the train cars set to the freight track (Figure 6).

4. Weighing empty carriages and loading them.

5. Pulling out the train cars set to the lift track no. 15a, in order to move it later to the dispatch and collect track no. 7 , with simultaneous weighing of the loaded carriages.

6. Shunting the loaded train cars set to the dispatch and collect track no. 7 (Figure 7).

7. Detaching the shunting engine (Figure 7).

8. Hooking the haulage contractor's engine.

9. Admission of an empty set of train cars to the dispatch and collect track no. 11 (Fig. 8).

10. Operational tests and shipping of the loaded train carriages set to the trail tracks (Fig. 8).

In order to verify the total mass of the train cars set before the shipping of the loaded unit to the trail tracks of PKP PLK S.A., a railway carriage weigh has been planned in the inset track of junctions $3 \mathrm{~N}$ and $9 \mathrm{~N}$, which allows to weight empty carriages before they are loaded and also carriages already loaded with the output.

The above analysis of loading time (4 hours and $15 \mathrm{mi}-$ nutes) applies only to the coalmine operation objects and does not take into account tracks occupancy by other users.

Taking into account the gradeline of the tracks, their inclination and train cars set mass, it is conceivable that it might be necessary to use an auxiliary engine, which has also been included in the present project. 


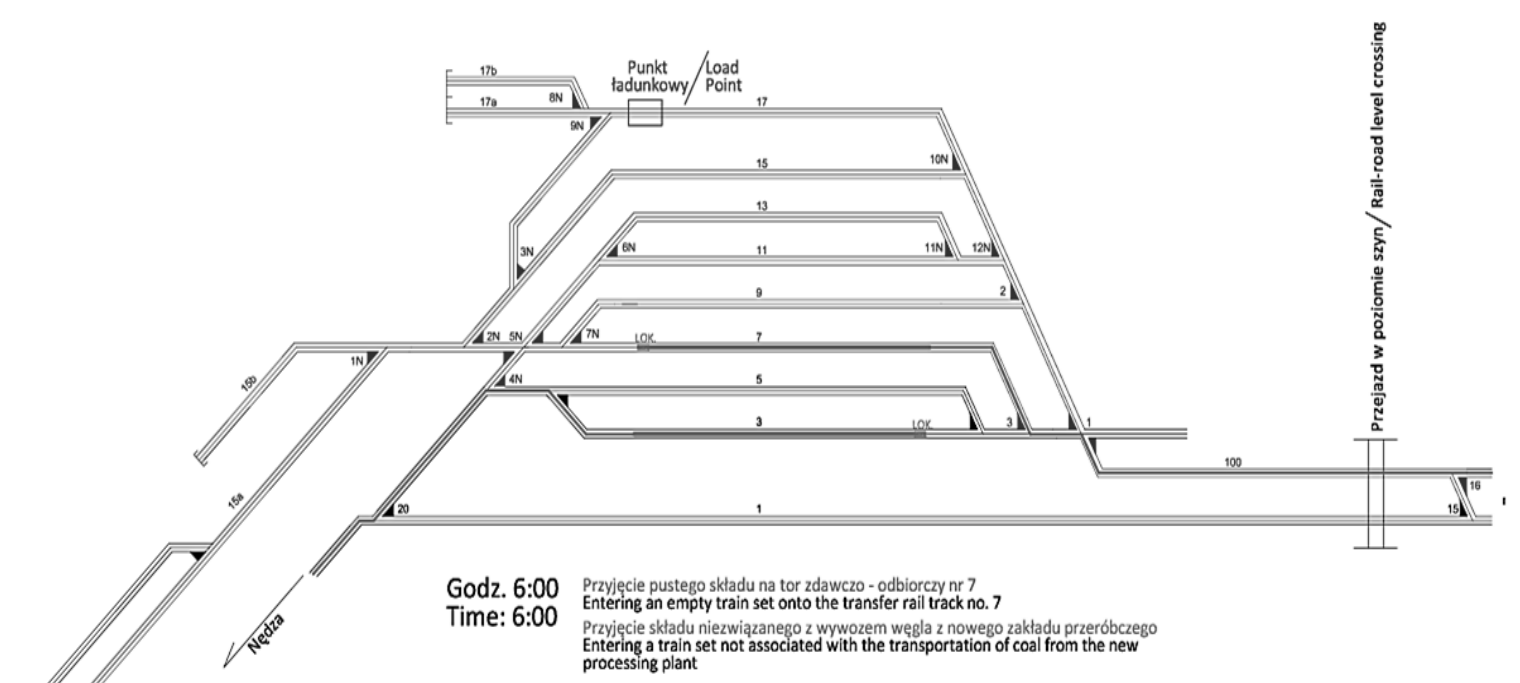

Legenda / Legend:

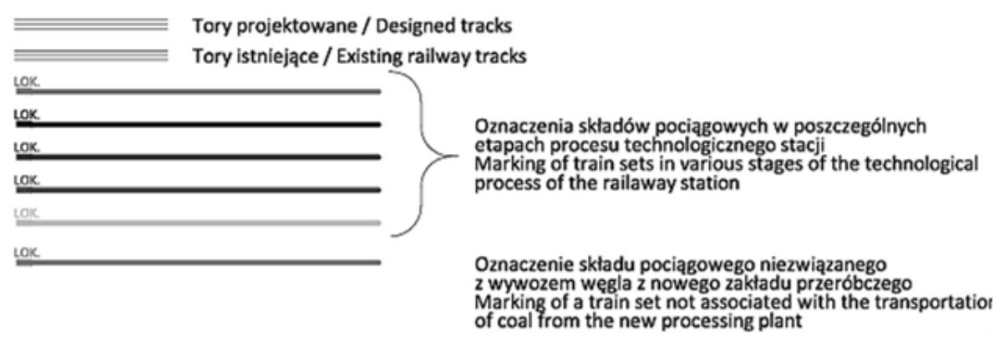

Fig. 4 Admission of an empty set of train cars at the dispatch and collect track Source: [6].



Fig. 5 Pulling out the train cars set from the dispatch and collect track to the lift track Source: [6]. 




Fig. 6 Shunting the train cars set to the freight track Source: [6].



Fig. 7 Shunting the loaded train cars set to the dispatch and collect track Source: [6].

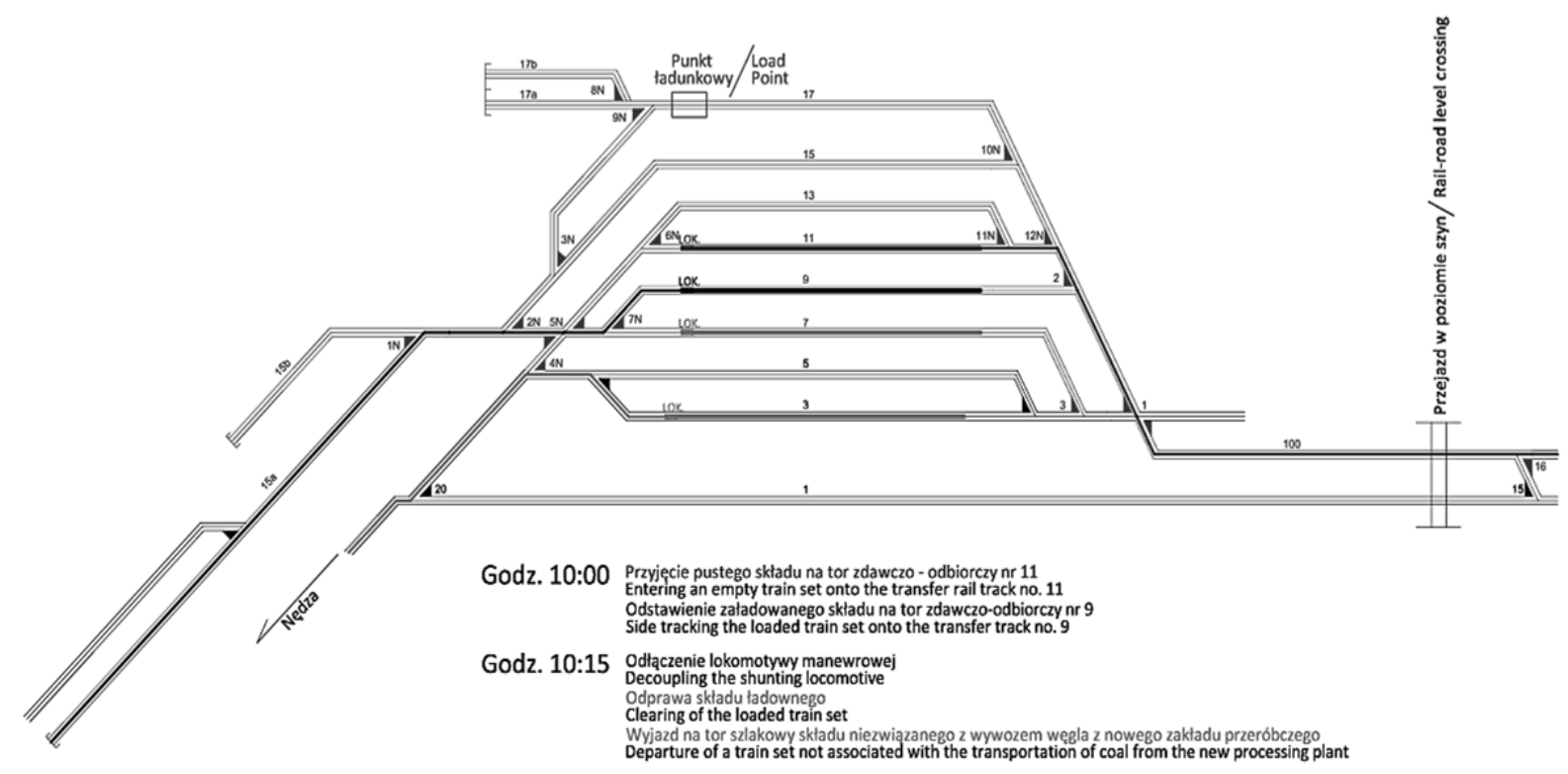

Fig. 8 Admission of an empty set of train cars to the dispatch and collect track no. 11 and shipping of the loaded train cars set Source: [6]. 


\section{SUMMARY AND CONCLUSIONS}

The company „Karbonia” S.A., which is part of the international firm New World Resources N.V. has obtained a license for extraction of bituminous coal and coal bed methane on the premises of the former Dębieńsko hard coalmine. With the view of launching a new mining plant called "Dębieńsko 1", the company has commissioned preparation two site development projects for the main plant area, and in particular the configuration of the railway line, by means of which the extracted coke is to be delivered to recipients.

It was designed a very scattered site development in the first project. It would generate logistic obstacles related to the transportation of materials and output between the shaft and locomotive terminal, located at the distance of over $300 \mathrm{~m}$. What is more, such a building development project would involve necessity to level off a large area of ground.

The first solution also assumed the railway line located nearby the Shaft VIII. However, it would require extensive excavation works that would generate high costs because the elevation spans achieve 10 to 16 meters. Moreover, the ordinate of the top of the narrow gauge track bed should be equal to the elevation ordinate of the shaft's outset. This ordinate equals $252,5 \mathrm{~m}$ above sea level, while the subsoil ordinate is on average $2 \mathrm{~m}$ higher. This would in turn require numerous digging works and would increase even more the already substantial costs of excavations.

Taking into account the above mentioned and some other drawbacks and defects, eventually the first conception has not been realised and has been rejected.

The second idea assumes the location of railway line in such a way to make use of the existing tracks no. 1, 3 and 5 (after their renovation). Additionally, nine new tracks have been planned in parallel layout (tracks no. 7, 9, 11, 13, 15, $17,17 \mathrm{a}, 17 \mathrm{~b}$ and 100) and two new tracks planned (15a and $15 \mathrm{~b}$ ) in cross-wise layout to the existing ones. This project has assumed connecting plant's station system with PKP PLK S.A. trail track by means of the track no. 100. A project for a new drainage system has been included in the planned and existing tracks, which would increase stability of the track beds and ground resistance during exploitation of the tracks. What is more, it would improve operation of the buildings and devices located nearby the rail line.
Moreover, the second conception includes implementation of new shipment and feedstock haulage technology, successfully used in the United States. It consists in weighing the output by loading equipment at runtime. The output portion, prepared in this way, is then dropped to a discharge hopper located above a passing railway carriage. The full shipment cycle of one $600 \mathrm{~m}$ long train cars set would take over 4 hours. This system and the new tracks layout would allow for operation of up to five sets of train cars within twenty-four hours.

All this and many more technical solutions and facilities, proper spatial arrangement of the newly designed objects, compatibility of the planned tracks with the existing rail infrastructure and also lower costs of the project realisation have determined the decision to choose the second conception of "Dębieńsko 1" mining plant site development prepared in variant I for realisation.

\section{REFERENCES}

[1] Act no. XXIX/375/13 of the City Council of CzerwionkaLeszczyny, of 22nd Feb 2013 about Local Zoning Plan for the mining area "Dębieńsko 1", which includes fragments of Czuchów, Czerwionka and Dębieńsko districts, 2013.

[2] Act no. IX/78/2002 of the City Council of CzerwionkaLeszczyny, of 26th Sept 2002 about Local Zoning Plan for Town and Municipality of Czerwionka-Leszczyny, 2002.

[3] E. Maciejowska-Figiel. „Projekt koncepcyjny zagospodarowania terenu zakładu górniczego »Dębieńsko 1"”, in Conference materials of Górnictwo Zrównoważonego Rozwoju, Gliwice, 2015, pp. 1-4.

[4] Study of Land Use Conditions and Directions of Czerwionka-Leszczyny (part A - study text), 2010.

[5] The first Program-Spatial Concept of "Dębieńsko 1" mining plant (no. 30597), 2013.

[6] The second project of „Dębieńsko 1" mining plant site development with the concept of track system (no. 14106.0-01.1), 2014.

[7] Projekt Dębieńsko, [Online]. Available: http:// www.nwrkarbonia.pl/pl/projekt-debiensko

Assoc. Prof. Ryszard Mielimąka PhD, Eng, DSc, Justyna Orwat MSc. Eng,

Ewa Maciejowska-Figiel MSc. Eng

Silesian University of Technology, Faculty of Mining and Geology

ul. Akademicka 2, 44-100 Gliwice, POLAND

e-mail: Ryszard.Mielimaka@polsl.pl

Justyna.Orwat@polsl.pl,

Ewa.Maciejowska-Figiel@polsl.pl 